NISTIR 6510

\title{
Simulation of the Dynamics of the Fire at 3146 Cherry Road NE Washington D.C., May 30, 1999
}

Daniel Madrzykowski

Robert L. Vettori 


\title{
Simulation of the Dynamics of the Fire at 3146 Cherry Road NE Washington D.C., May 30, 1999
}

\author{
Daniel Madrzykowski \\ Robert L. Vettori \\ Building and Fire Research Laboratory \\ National Institute of Standards and Technology \\ Gaithersburg, MD 20899-8644
}

April 2000

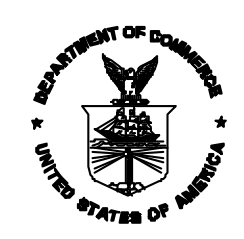

U.S. Department of Commerce William M. Daley, Secretary

Technology Administration Dr. Cheryl L. Shavers, Under Secretary of Commerce for Technology

National Institute of Standards and Technology Raymond G. Kammer, Director 


\section{TABLE OF CONTENTS}

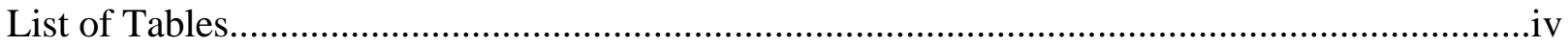

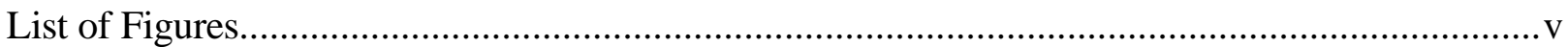

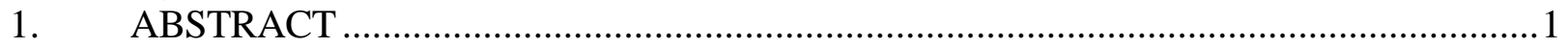

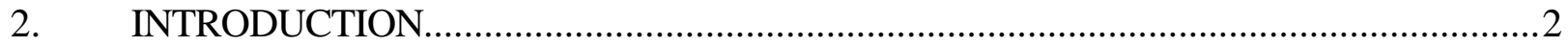

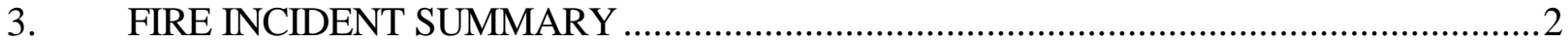

4. NIST FIRE DYNAMICS SIMULATOR (FDS) ....................................................

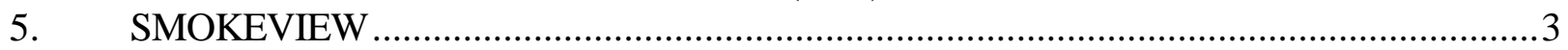

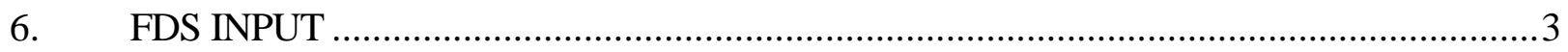

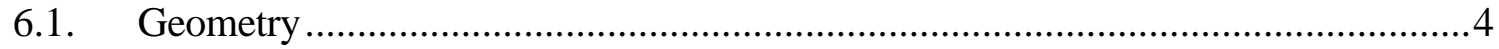

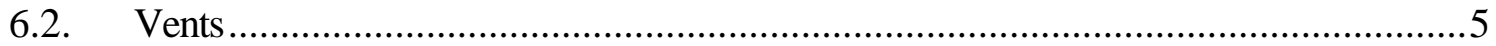

6.3. Material Properties................................................................................ 6

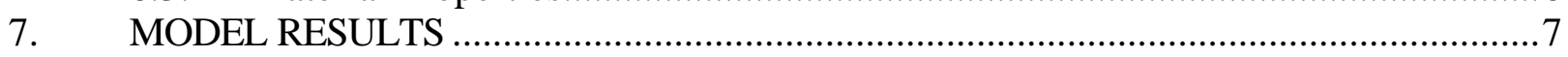

7.1. Heat Release Rate of Fire........................................................................... 7

7.2. $\quad$ Fire Simulation 1 - Reported Fire Events - Temperature, Velocity, and Oxygen Concentration Predictions................................................................................. 7

7.3. Fire Simulation 2 - Opening of the Sliding Glass Door on the First Floor Prior to the Opening of the Sliding Glass Door in the Basement - Temperature and Velocity

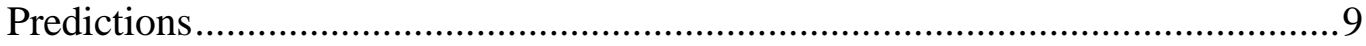

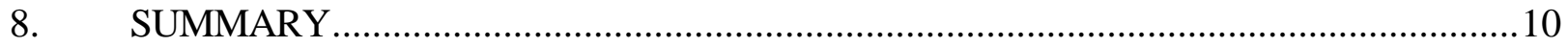

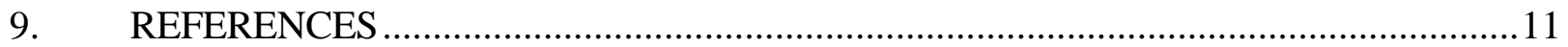




\section{LIST OF TABLES}

Table 1. Approximate Timeline Based on Reconstruction Committee Input...............................4

Table 2. Time of Ventilation Events for FDS Simulation ..................................................5

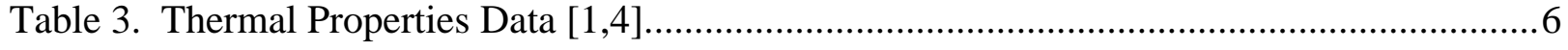

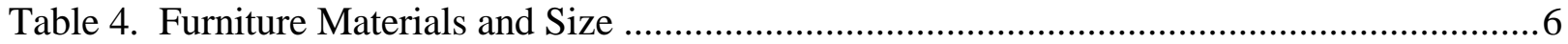




\section{LIST OF FIGURES}

Figure 1. Plan view of first floor .............................................................................. 12

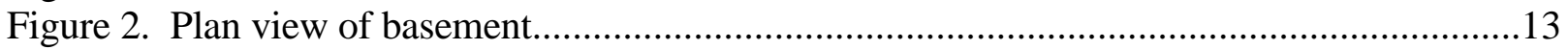

Figure 3. Heat release rate from FDS Simulation..........................................................14

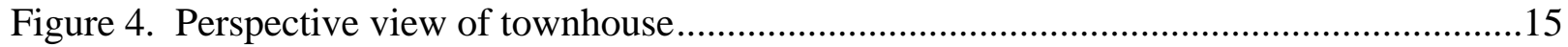

Figure 5. Grid layout in the $\mathrm{xz}$ plane ............................................................................16

Figure 6. Temperature slice along basement sliding glass door, at $200 \mathrm{~s}$ of simulation. ............17

Figure 7. Vector representation of velocity slice along basement sliding glass door, at

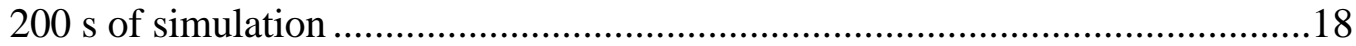

Figure 8. Temperature slice along front door, at $200 \mathrm{~s}$ of simulation. ..................................19

Figure 9. Vector representation of velocity slice along front door, at $200 \mathrm{~s}$ of simulation. .........20

Figure 10. Temperature slice along centerline of stairway, at $200 \mathrm{~s}$ of simulation....................21

Figure 11. Vector representation of velocity along centerline of stairway, at $200 \mathrm{~s}$ of

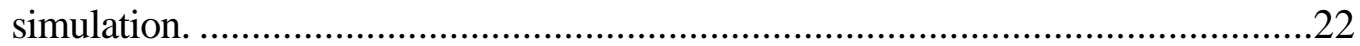

Figure 12. Percent oxygen along basement sliding glass door, at $200 \mathrm{~s}$ of simulation................23

Figure 13. Percent oxygen along centerline of stairway, at $200 \mathrm{~s}$ of simulation........................24

Figure 14. Vector representation of velocity at the ceiling, at $200 \mathrm{~s}$ of simulation....................25

Figure 15. Vector representation of velocity at first floor window, $1.6 \mathrm{~m}$ off the

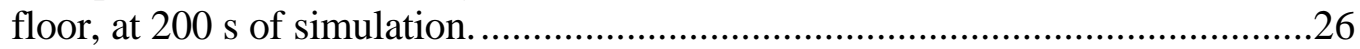

Figure 16. Temperature slice along centerline of stairway with first floor sliding glass door vented, at $200 \mathrm{~s}$ of simulation............................................................2.

Figure 17. Vector representation of velocity at the ceiling with first floor sliding glass door vented, at $200 \mathrm{~s}$ of simulation. 
Simulation of the Dynamics of the Fire at 3146 Cherry Road NE, Washington D.C.

May 30, 1999

\author{
Daniel Madrzykowski \\ Robert L. Vettori
}

\title{
1. ABSTRACT
}

This report describes the results of calculations using the NIST Fire Dynamics Simulator (FDS) that were performed to provide insight on the thermal conditions that may have occurred during the fire at 3146 Cherry Road NE, Washington D.C. on May 30, 1999. Input to the computer model was developed from 3 sources; the District of Columbia Fire and Emergency Medical Services Department Reconstruction Committee, photographs and measurements taken by NIST staff during a June 3, 1999 site visit, and from material properties taken from the FDS database.

An FDS model scenario was developed that best represented the actual building geometry, material thermal properties, and fire behavior based on information from the Reconstruction Committee and physical evidence. The results from this model scenario are provided with this report. Results from an additional model scenario, which included the opening of the sliding glass door on the first floor prior to opening of the sliding glass door in the basement, are also presented.

The FDS calculations that best represent the reported fire conditions indicate that the opening of the basement sliding glass doors provided outside air (oxygen) to a pre-heated, under ventilated fire compartment, which then developed into a post-flashover fire within $60 \mathrm{~s}$. Some of the resulting fire gases flowed up the basement stairwell with high velocity and collected in a pre-heated, oxygen depleted first floor living room with limited ventilation.

Key Words: cfd models; computer graphics; fire dynamics; fire fatalities; fire fighters; fire investigations; fire models; fire simulations; ventilation 


\section{INTRODUCTION}

Part of the mission of the Building and Fire Research Laboratory (BFRL) at the National Institute of Standards and Technology (NIST) is to conduct basic and applied fire research, including fire investigations, for the purposes of understanding fundamental fire behavior and to reduce losses from fire.

On May 30, 1999 a fire in a townhouse at 3146 Cherry Road NE, Washington D.C. claimed the lives of two District of Columbia firefighters and burned other firefighters. The District of Columbia Fire and Emergency Medical Services Department Reconstruction Committee requested the assistance of NIST for the purpose of examining the fire dynamics of this incident. NIST has performed computer simulations of the fire using the newly developed, NIST Fire Dynamics Simulator (FDS) and Smokeview, a visualization tool, to provide insight on the fire development and thermal conditions that may have existed in the townhouse during the fire. This document describes the input and the results of the NIST FDS calculations.

\section{FIRE INCIDENT SUMMARY}

This account of the events relevant to the fire at 3146 Cherry Road NE is based on information provided to NIST by the Reconstruction Committee. Shortly after midnight, on May $30^{\text {th }}, 1999$, occupants at 3146 Cherry Road, NE awoke to a smoke alarm that had activated in the residence. The occupants went downstairs to the first floor, found hot smoky conditions, and exited the residence via the front door, leaving the front door open. At 00:17:00 hrs, the first 911 call was received. The first engine arrived on the fire scene in approximately 6 minutes. At approximately 00:24:00, firefighters began entering the first floor via the front door. Conditions on the first floor were described as "heavy smoke," with thick black smoke coming from the doorway. Within two minutes, the front window on first floor was taken out by firefighters to provide ventilation. The window was removed from the inside, due to obstructions from security bars on the outside. Firefighters were also opening the second story windows on the front of the house. The occupants had left the second story windows on the backside of the house open.

Firefighters positioned by the sliding glass doors on the basement level reported that the basement was fully charged with smoke and that upon arrival a few flames appeared briefly. The sliding glass door was broken out in two stages. First, the right half was taken out at approximately 00:26:20. Then the left side was removed approximately $20 \mathrm{~s}$ later, due to obstructions from security bars. After the sliding glass door was broken out, firefighters entered the basement to conduct a search. They reported that there were a number of small fires on the floor of the basement, and that the fires began to increase in size after the sliding glass door was opened. The firefighters were ordered out of the basement as the fire rapidly increased in size. The firefighters reported that a tunnel or path was open in the smoke that enabled them to find their way out of the basement to the exterior, just prior to the basement becoming fully involved with fire. Within two minutes after entering the basement, flames from the basement extended up the backside of the townhouse. Seconds later there was a report that a firefighter was down. Firefighters that were working on the first floor reported that they felt an intense blast of heat prior to exiting the building. Two of the firefighters working on the first floor, one positioned near the open doorway to the basement stairs and the other located near the sofa on the back 
wall of the townhouse, died from injuries caused by the fire. A third firefighter, positioned between the two firefighters that died, survived the fire, but sustained substantial burn injuries.

The post fire investigation determined that the fire started near an electrical fixture in the ceiling of the basement. The basement had severe fire damage throughout, indicating a well-mixed, post-flashover fire environment. The stairway from the basement to the first floor also showed signs of flame impingement on the ceiling and walls. The door at the top of the basement stairs was open during the fire and had been partially burned away. The basement stairway opened into the living room on the first floor. The living room had significant deposits of soot throughout, with limited thermal damage. Most of the paper on the gypsum board walls and ceiling remained intact and sofas in the room only showed signs of pyrolization or limited burning on the upper portions of the back cushions and top surfaces of the seat cushions. Areas in the living room away from the basement door opening had less thermal damage.

\section{NIST FIRE DYNAMICS SIMULATOR (FDS)}

NIST has developed a computational fluid dynamics (CFD) fire model using large eddy simulation (LES) techniques [1]. This model, called the NIST Fire Dynamics Simulator (FDS), has been demonstrated to predict the thermal conditions resulting from a compartment fire [2,3]. A CFD model requires that the room or building of interest be divided into small rectangular control volumes or computational cells. The CFD model computes the density, velocity, temperature, pressure and species concentration of the gas in each cell, based on the conservation laws of mass, momentum, and energy, to model the movement of fire gases. FDS utilizes material properties of the furnishings, walls, floors, and ceilings to simulate fire growth and spread. A complete description of the FDS model is given in reference [1].

In large scale fire tests reported in [2], FDS temperature predictions were found to be within $15 \%$ of the measured temperatures and the FDS heat release rates were predicted to within $20 \%$ of the measured values [2]. For relatively simple fire driven flows, such as buoyant plumes and flows through doorways, FDS predictions are within experimental uncertainties [3]. Therefore the results are presented as ranges to account for this uncertainty.

\section{SMOKEVIEW}

Smokeview is a visualization program that was developed to display the results of a FDS model simulation. Smokeview produces animations or snapshots of FDS results [4].

\section{FDS INPUT}

FDS requires as inputs the geometry of the building compartments being modeled, the computational cell size, the location of the ignition source, the ignition source, thermal properties of walls and furnishings, and the size, location, and timing of vent openings to the outside which critically influence fire growth and spread. The timing of the vent openings, Table 2, used in the simulation is based on an approximate timeline of the fire fighting activities in Table 1. 
Table 1. Approximate Timeline Based on Reconstruction Committee Input

Incident Time

\section{Simulation Time}

(s)
00:17:00 First call reporting fire.
00:18:40 Second call - "fire in basement"
00:23:00 Engine 26 on scene - "heavy smoke showing"
00:24:00 Engine 26 and Engine 10 firefighters enter front door. Engine 17 layout.
00:24:50 Battalion Chief 1 directs Truck 4 to rear.
00:26:00 First floor front window removed.
120
00:26:20 Basement sliding glass door half out. 140
00:26:30 Firefighters from Rescue Squad 1 and Truck 4 enter basement. $\quad 150$
00:26:40 Basement sliding glass door completely out. 160
00:26:50 Engine 17 firefighters in the rear, "fire small in basement" $\quad 170$
00:27:20 Firefighters from Rescue Squad 1 and Truck 4 exit basement. 200 "basement almost fully involved"
00:28:00 Estimated time that firefighters from Engine 26 and Engine $10 \quad 240$
00:28:40 Engine 17 in rear, "fire extending to first floor" 280
00:29:00 (End of simulation time) 300

Note: Direct comparison of simulation conditions with the actual incident conditions begin at approximately $100 \mathrm{~s}$ of simulation time.

\subsection{Geometry}

The floor plans of the basement and first floor of the townhouse are shown in Figures 1 and 2. The two levels of the townhouse are modeled by a $10.0 \mathrm{~m}(32.8 \mathrm{ft}) \times 6.0 \mathrm{~m}(19.7 \mathrm{ft}) \times 5.1 \mathrm{~m}(16.8 \mathrm{ft})$ tall rectangular volume. For the FDS simulation this volume was divided into 76,500 computational cells. Each cell has dimensions $0.2 \mathrm{~m}$ (7.9 in) $\mathrm{x} 0.2 \mathrm{~m}$ (7.9 in) $\mathrm{x} 0.1 \mathrm{~m}$ (3.9 in). The placement and size of the interior walls, doorways, and windows were taken from the dimensioned floor plans drawn by personnel of the DC Fire and EMS Department. FDS adjusts the dimensions to the nearest computational cell. Therefore the cell size is the resolution limit of vents, openings, furnishings, or walls within the model. The cell size was selected to give the best approximation of the actual dimensions of the townhouse geometry. 


\subsection{Vents}

The basement was vented to the outside by a sliding glass door $1.7 \mathrm{~m}(5.6 \mathrm{ft}) \times 2.0 \mathrm{~m}(6.6 \mathrm{ft})$ high. For the simulation, the door vent was divided into two parts. The right half of the sliding glass door was opened at $140 \mathrm{~s}$ into the simulation and the left half was opened at $160 \mathrm{~s}$ into the simulation.

The basement was open to the first floor by a $0.8 \mathrm{~m}(2.6 \mathrm{ft})$ x $2.0 \mathrm{~m}(6.6 \mathrm{ft})$ high doorway at the top of the stairs. As in the fire incident, this door was fully open during the simulation. The front door to the first floor was also fully open during the fire and the simulation. The door was $0.9 \mathrm{~m}(3.0 \mathrm{ft})$ wide and $2.0 \mathrm{~m}(6.6 \mathrm{ft})$ high. The front window on the first floor was $1.7 \mathrm{~m}(5.6 \mathrm{ft})$ wide and $0.9 \mathrm{~m}(3.0 \mathrm{ft})$ high with a $0.9 \mathrm{~m}(3.0 \mathrm{ft})$ sill height. This window was opened at $120 \mathrm{~s}$ into the simulation. The other opening to the outside from the first floor was a sliding glass door at the rear of the house. This sliding glass door was located directly above the basement sliding glass door. This door remained closed and intact during the entire simulation.

The stairway opening from the first floor to the second floor was $0.9 \mathrm{~m}(3.0 \mathrm{ft})$ wide and $3.4 \mathrm{~m}$ $(11.2 \mathrm{ft})$ deep. This vent remained open during the entire simulation due to the windows in the front and rear of the second floor being open. The exact position of the open rear windows on the second floor is not known; therefore the stairway opening was used to represent the assumed area of the open second floor windows. The details of the second floor were not modeled in this simulation.

At the time of the fire there was no wind, therefore for the simulation it was assumed that openings to the exterior were at ambient pressure.

Table 2. Time of Ventilation Events for FDS Simulation

\begin{tabular}{|l|c|c|c|c|}
\hline \multicolumn{1}{|c|}{ Vent } & \multicolumn{3}{c|}{ Time of Event } \\
\hline Front Door & $\begin{array}{c}\text { Initial } \\
\text { Conditions }\end{array}$ & $120 \mathrm{~s}$ & $140 \mathrm{~s}$ & $160 \mathrm{~s}$ \\
\hline Front Window & Open & Open & Open & Open \\
\hline $\begin{array}{l}\text { First half of basement } \\
\text { sliding glass door }\end{array}$ & Closed & Open & Open & Open \\
\hline $\begin{array}{l}\text { Second half of basement } \\
\text { sliding glass door }\end{array}$ & Closed & Closed & Closed & Open \\
\hline $\begin{array}{l}\text { Stairway door between } \\
\text { basement \& first floor }\end{array}$ & Open & Open & Open & Open \\
\hline $\begin{array}{l}\text { Stairway opening between } \\
\text { first and second floor }\end{array}$ & Open & Open & Open & Open \\
\hline
\end{tabular}




\subsection{Material Properties}

The ceiling of the basement was composed of wood fiber ceiling tiles attached to wood furring strips, which were attached to the bottom of open wood trusses. Given the multiple surfaces in the ceiling floor system, several different approximations were used for the ignition temperature $\left(320{ }^{\circ} \mathrm{C}\right.$ to $\left.390{ }^{\circ} \mathrm{C}\right)$ and the heat release rate per unit area $\left(200 \mathrm{~kW} / \mathrm{m}^{2}\right.$ to $\left.400 \mathrm{~kW} / \mathrm{m}^{2}\right)$. The assumptions used for the basement ceiling materials are shown in Table 3 .

The walls of the townhouse were painted gypsum board, assumed $12 \mathrm{~mm}(0.5 \mathrm{in})$ thick. The subflooring was plywood and was covered with carpeting in the living room area of the house. The ceiling on the first floor was also painted gypsum board. Several large furniture items were included in the scenario; a bookcase, bar, desk and sofa in the basement as well as a door and sofa on the first floor. The model inputs utilized for each material type are given below in Table 3 and the size of the furnishings are given in Table 4.

Table 3. Thermal Properties Data [1,4]

\begin{tabular}{|l|c|c|c|c|c|}
\hline \multicolumn{1}{|c|}{ Material } & Thickness & $\begin{array}{c}\text { Ignition } \\
\text { Temperature } \\
(\mathrm{m})\end{array}$ & $\begin{array}{c}\text { Heat } \\
\text { Release } \\
\text { Rate } \\
\left(\mathrm{kW} / \mathrm{m}^{2}\right)\end{array}$ & $\begin{array}{c}\text { Thermal } \\
\text { Conductivity } \\
(\mathrm{W} / \mathrm{m} \mathrm{K})\end{array}$ & $\begin{array}{c}\text { Thermal } \\
\text { Diffusivity }\end{array}$ \\
\hline $\begin{array}{l}\text { Basement } \\
\text { Ceiling }\end{array}$ & 0.025 & 330 & 300 & 0.14 & $8.3 \mathrm{E}-8$ \\
\hline $\begin{array}{l}\text { Gypsum } \\
\text { Board }\end{array}$ & 0.013 & 400 & 100 & 0.48 & $4.1 \mathrm{E}-7$ \\
\hline Pine & 0.013 & 390 & 200 & 0.14 & $8.3 \mathrm{E}-8$ \\
\hline $\begin{array}{l}\text { Upholstered } \\
\text { Cushion }\end{array}$ & 0.10 & 370 & 700 & 0.20 & $1.2 \mathrm{E}-6$ \\
\hline
\end{tabular}

Table 4. Furniture Materials and Size

\begin{tabular}{|l|l|l|}
\hline \multicolumn{1}{|c|}{ Item } & \multicolumn{1}{c|}{ Material } & \multicolumn{1}{c|}{ Size } \\
\hline Bookcase & Pine & $2 \mathrm{~m}$ wide, $0.3 \mathrm{~m}$ deep, $2.4 \mathrm{~m}$ high \\
\hline Bar & Pine & $2 \mathrm{~m}$ wide, $1 \mathrm{~m}$ deep, $1.2 \mathrm{~m}$ high \\
\hline Desk & Pine & $1.5 \mathrm{~m}$ wide, $0.75 \mathrm{~m}$ deep, $0.75 \mathrm{~m}$ high \\
\hline Sofa & Upholstered cushion & $2 \mathrm{~m}$ wide, $0.75 \mathrm{~m}$ deep, $0.9 \mathrm{~m}$ high \\
\hline $\begin{array}{l}\text { First floor door to } \\
\text { basement }\end{array}$ & Pine & $0.85 \mathrm{~m}$ wide, $0.05 \mathrm{~m}$ thick, $2.05 \mathrm{~m}$ high \\
\hline
\end{tabular}




\section{MODEL RESULTS}

\subsection{Heat Release Rate of Fire}

For the FDS simulation, a small fire with a specified heat release rate was used to start the fire growth. In this case a $30 \mathrm{~kW}$ source, $0.2 \mathrm{~m}$ ( 8 in) square, located $0.1 \mathrm{~m}$ (4 in) below the basement ceiling, served as the FDS fire source. Starting the simulation with a flaming ignition enabled fire development to be modeled within a reasonable computational time. The actual fire may have taken several hours to develop to the flaming stage. As the simulated fire spreads from the ignition source, first along the ceiling and then to other items in the basement, it develops quickly, but depletes its supply of oxygen for combustion. This rapidly decreases the heat release rate or energy that is being produced by the fire. This produced a pre-heated oxygen depleted condition similar to that described by firefighters upon their arrival at the Cherry Road fire.

A time history of the fire's heat release rate, as predicted by FDS, is shown in Figure 3. Annotations on the figure highlight the venting activities and the resulting impact on the development of the fire. As shown in the graph, venting the basement results in a heat release rate increase of more than 10,000 $\mathrm{kW}$ or $10 \mathrm{MW}$ within approximately one minute.

\subsection{Fire Simulation 1 - Reported Fire Events - Temperature, Velocity, and Oxygen Concentration Predictions}

Figure 4 shows a perspective view of the three-dimensional townhouse simulation. The basement level and first floor levels are shown with furnishings. Figure 5 provides a side view of the townhouse. The grid depicting the computational cell size is also shown. The simulation results in Figures 6 through 15 have had all of the walls and other obstructions removed to provide a clear view. The horizontal clear area is the floor between the basement and the first floor level. The results are shown as a "slice" or a "plane" with a color bar that represents the corresponding numerical quantities. The results presented are taken at $200 \mathrm{~s}$ of the simulation. At that time, the heat release rate and the thermal conditions have reached a quasi-steady state condition. These figures provide a snapshot of the calculated fire environment conditions that the firefighters may have been exposed to at approximately 00:27:20.

Figures 6 and 7 show the plane of temperatures and velocities that align with the center of the first sliding glass panel that was taken out on the basement level. This plane is located $3.4 \mathrm{~m}(11.2 \mathrm{ft})$ into the townhouse from the front of Figures 6 and 7. The upper portions of the figures represent the kitchen area on the left and the living room area on the right. In Figure 6, temperatures in excess of $820^{\circ} \mathrm{C}\left(1500^{\circ} \mathrm{F}\right)$ are shown throughout the basement, with the exception of the cool air entering the basement through the open sliding glass doorway at the right of the figure. Similar hot gas temperature conditions exist in the living room area. The maximum temperatures in the kitchen are in the $500^{\circ} \mathrm{C}$ to $660{ }^{\circ} \mathrm{C}\left(932^{\circ} \mathrm{F}\right.$ to $\left.1220^{\circ} \mathrm{F}\right)$ range. The velocity vector plot in Figure 7 provides gas flow direction as well as the approximate velocities. The dominant flows in this plane are the fresh air entering the open basement doorway at approximately $4 \mathrm{~m} / \mathrm{s}(10 \mathrm{mph})$ and the hot gas flow exiting the upper portion of the doorway at approximately $7 \mathrm{~m} / \mathrm{s}(16 \mathrm{mph})$. 
Figures 8 and 9 show the plane of temperatures and velocities aligned with the center of the front door and the hallway, $1.4 \mathrm{~m}(4.6 \mathrm{ft})$ into the townhouse from the front of the figure. The upper portions of the figures represent the hallway and living room areas and the lower portions represent the open area in the basement on the left and an area in the storage room (cooler temperatures) on the right. Predicted temperatures in the open area of the basement are in excess of $820^{\circ} \mathrm{C}\left(1500^{\circ} \mathrm{F}\right)$, from the ceiling to the floor level in some areas. On the first floor, hot gases can be seen along the ceiling, cooling as the gases move from the back of the townhouse to the front. Outside air at approximately 20 ${ }^{\circ} \mathrm{C}\left(68^{\circ} \mathrm{F}\right)$ can be seen entering the front door from the left. The gas moving into the townhouse, along the floor, from the front door increases from $180^{\circ} \mathrm{C}$ to $260^{\circ} \mathrm{C}\left(350^{\circ} \mathrm{F}\right.$ to $\left.500^{\circ} \mathrm{F}\right)$ by the time it reaches the back of the townhouse (right side of figure).

The flow direction of the gases can be seen in Figure 9. On the first floor, outside air is entering the lower portion of the open front doorway in the range of $4 \mathrm{~m} / \mathrm{s}$ to $5.6 \mathrm{~m} / \mathrm{s}$ (10 mph to $12.5 \mathrm{mph}$ ). Hot gases are exiting the upper portion of the same doorway with maximum velocities in the range of $5.6 \mathrm{~m} / \mathrm{s}$ to $6.4 \mathrm{~m} / \mathrm{s}$ (12.5 mph to $14 \mathrm{mph})$. Toward the rear of the townhouse on the first floor, hot gas flows from the basement doorway in excess of $8 \mathrm{~m} / \mathrm{s}(18 \mathrm{mph})$.

Figures 10 and 11 show the plane of temperatures and velocities that align with the center of the basement stairway, $0.4 \mathrm{~m}(1.3 \mathrm{ft})$ into the townhouse from the front of the figure. The temperature plot shows hot gases in excess of $820^{\circ} \mathrm{C}\left(1500^{\circ} \mathrm{F}\right)$ filling the stairwell, flowing out into the living room, across the living room ceiling and down the back wall. The clear-notched area on the right side is the outline of the sofa. Between the doorway to the basement and the sofa, the temperatures approximately $0.5 \mathrm{~m}(1.6 \mathrm{ft})$ above the floor, to floor level are in the range of $180^{\circ} \mathrm{C}$ to $260^{\circ} \mathrm{C}\left(350{ }^{\circ} \mathrm{F}\right.$ to $\left.500{ }^{\circ} \mathrm{F}\right)$. The areas near the floor where the temperatures were the highest, were near the doorway to the stairs and near the sofa on the back wall. These locations correspond to the areas where the two firefighter fatalities were believed to have occurred.

Figure 11 shows the effect of the stairway on channeling the hot gases up to the first floor. The speed at which the fire gases flow up the stairway and across the ceiling of the first floor exceed $8 \mathrm{~m} / \mathrm{s}$ (18 $\mathrm{mph}$ ). At these velocities, the travel time for the gases from the front of the basement (left side of figure) to the back of the first floor (right side of figure) is less than $2 \mathrm{~s}$. Between the doorway to the basement and the sofa, the velocities from approximately $0.5 \mathrm{~m}(1.6 \mathrm{ft})$ above the floor to floor level are in the range of $0 \mathrm{~m} / \mathrm{s}$ to $1.6 \mathrm{~m} / \mathrm{s}(0 \mathrm{mph}$ to $3.5 \mathrm{mph})$. The right side of the basement shown is the storage area under the stairs.

Figures 12 and 13 show oxygen concentrations. Even though the previous temperature plots have indicted temperatures that are consistent with flaming conditions, that cannot be assumed. In addition to fuel and heat, oxygen is needed for flaming combustion to be present. These figures provide some insight on the amount of oxygen that was available in different parts of the townhouse. The upper, hot gas layers in the basement and on the first floor in the living room area contained less than $6 \%$ oxygen (all gas percents are on a volumetric basis). These are areas where the fire may not have had enough oxygen to produce visible flames.

Figure 12 shows the slice aligned with the center of the right side of the basement sliding glass door. Again the outside air can be seen entering the basement through the open doorway from the lower right 
side of the plot. A thin layer of $16 \%$ to $19 \%$ oxygen can be seen close to the floor on the first floor. This airflow is coming from the front door.

Figure 13 gives a view of the oxygen conditions along the centerline of the basement stairway. The hot gases that are flowing up from the basement are oxygen depleted, ranging from $14 \%$ to $16 \%$ oxygen at the base of the stairs and decreasing to $6 \%$ to $11 \%$ oxygen at the top of the stairs. The high velocity hot gas layer that flows across the living room ceiling and down the back wall of the townhouse (right side of figure) contains less than $6 \%$ oxygen. Given the oxygen depleted conditions, little if any flaming combustion would be taking place in the living room area this time. The right portion of the basement represents the storage area under the steps.

Figures 14 and 15 show the velocity flow patterns near the ceiling of the first floor and at approximately $1.6 \mathrm{~m}(5.2 \mathrm{ft})$ above the floor, respectively. The velocities in front of the doorway to the basement are in the range of $8 \mathrm{~m} / \mathrm{s}(18 \mathrm{mph})$. Figure 15 shows the circulation of gases from the doorway to the basement, across the back wall of the townhouse and then out the front window. Velocities flowing through the house in this U- shaped pattern range from $0.80 \mathrm{~m} / \mathrm{s}$ to $4.8 \mathrm{~m} / \mathrm{s}$ ( $2 \mathrm{mph}$ to $11 \mathrm{mph}$ ) at this level. These velocities coupled with the high gas temperatures will increase the rate of convective heat transfer to people or objects in that area.

\subsection{Fire Simulation 2 - Opening of the Sliding Glass Door on the First Floor Prior to the Opening of the Sliding Glass Door in the Basement - Temperature and Velocity Predictions}

At the request of the Reconstruction Committee, a second fire simulation was conducted. All of the input to the second simulation was the same as the first, with one exception; the sliding glass door in the living room on the first floor of the house was opened at 120 s into the simulation. In the basement, results of the second simulation were similar to the first. On the first floor the hot gases were not as confined as in simulation 1 resulting in cooler temperatures near the floor.

Figure 16 shows the plane of temperatures that align with the center of the basement stairway, $0.4 \mathrm{~m}$ $(1.3 \mathrm{ft})$ into the townhouse from the front of the figure. The temperature plot shows hot gases in excess of $820^{\circ} \mathrm{C}\left(1500^{\circ} \mathrm{F}\right)$ filling the stairwell, flowing out into the living room, across the living room ceiling and down the back wall. The clear-notched area on the right side is the outline of a sofa. This hot gas ceiling jet is similar to the hot gas conditions shown in Figure 10. The significant difference is in the region close to the floor. Between the doorway to the basement and the sofa, the temperatures

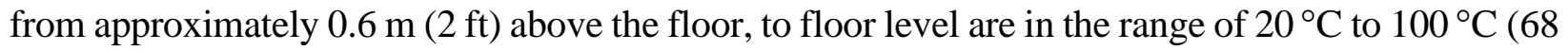
${ }^{\circ} \mathrm{F}$ to $\left.212^{\circ} \mathrm{F}\right)$. This is at least an $80{ }^{\circ} \mathrm{C}\left(176^{\circ} \mathrm{F}\right)$ temperature reduction in this area with the open sliding glass doorway on the first floor.

Figure 17 shows the velocity field at the ceiling of the first floor. Comparing this to Figure 14 shows that the velocity range is similar, approximately $8.5 \mathrm{~m} / \mathrm{s}(19 \mathrm{mph}) \mathrm{vs} .8 \mathrm{~m} / \mathrm{s}(18 \mathrm{mph})$. The flow pattern at the ceiling is wider for the second simulation because part of the flow stream is going out of the open sliding glass doorway. 


\section{SUMMARY}

The NIST FDS computer simulation predicted fire conditions and events that correlate well with information from the Reconstruction Committee and the damage, or lack of damage, to portions of the townhouse. The model simulated a fire that started in a combustible ceiling assembly in the basement of the townhouse. The fire grew and spread across the ceiling and into other fuels in the basement until it exhausted the available oxygen supply in the basement. While the fire's heat release rate was being constrained by the lack of oxygen, firefighters made entry on the first floor of the building. Venting of the windows on the front of the townhouse on the first and second floors had no noticeable immediate impact on the fire development.

However, the venting of the sliding glass doors in the basement increased the heat release rate of the fire very rapidly. The FDS calculation indicates that the opening of the basement sliding glass doors provided outside air (oxygen) to a pre-heated, under-ventilated fire compartment, which then developed into a post-flashover fire within $60 \mathrm{~s}$. The fire filling the basement forced high temperature gases (approximately $\left.820^{\circ} \mathrm{C}\left(1500^{\circ} \mathrm{F}\right)\right)$ up the basement stairwell at velocities in excess of $8 \mathrm{~m} / \mathrm{s}(18$ $\mathrm{mph}$ ). The high velocity gas stream flowed into a pre-heated, oxygen depleted first floor living room. The FDS predictions show the hot gas flow moving across the living room ceiling and banking down the back wall of the townhouse. Between the doorway to the basement and the sofa on the back wall of the townhouse, the temperatures from approximately $0.5 \mathrm{~m}(1.6 \mathrm{ft})$ above the floor, to floor level are in the range of $180{ }^{\circ} \mathrm{C}$ to $260{ }^{\circ} \mathrm{C}\left(350{ }^{\circ} \mathrm{F}\right.$ to $\left.500{ }^{\circ} \mathrm{F}\right)$. These thermal conditions developed within seconds of the rapid fire growth in the basement.

Even though the upper layer hot gases have predicted temperatures that are consistent with flaming conditions, that cannot be assumed. In addition to fuel and heat, oxygen is needed for flaming combustion to be present. The upper, hot gas layers in the basement and on the first floor in the living room area contained less than $6 \%$ oxygen when the basement fire was fully developed and extending up the stairs. These are areas, particularly the living room, where the fire may not have had enough oxygen to produce visible flames.

A second NIST FDS simulation was performed. The only difference was the opening of the sliding glass door on the first floor at $120 \mathrm{~s}$ of the simulation or $20 \mathrm{~s}$ prior to opening the basement sliding glass door. The most significant difference in the predictions is in the region close to the living room floor. Between the doorway to the basement and the sofa, the temperatures from approximately $0.6 \mathrm{~m}$ ( $2 \mathrm{ft}$ ) above the floor, to floor level are in the range of $20{ }^{\circ} \mathrm{C}$ to $100{ }^{\circ} \mathrm{C}\left(68^{\circ} \mathrm{F}\right.$ to $\left.212^{\circ} \mathrm{F}\right)$. This is at least an $80^{\circ} \mathrm{C}\left(176^{\circ} \mathrm{F}\right)$ temperature reduction in this area with the open sliding glass doorway on the first floor as compared to the first simulation with the door closed. 


\section{REFERENCES}

1. McGrattan, Kevin B., Baum, Howard R., Rehm, Ronald G., Hamins, Anthony, Forney, Glenn P., Fire Dynamics Simulator - Technical Reference Guide, National Institute of Standards and Technology, Gaithersburg, MD., NISTIR 6467, January 2000.

2. McGrattan, Kevin B., Hamins, Anthony, and Stroup, David, Sprinkler, Smoke \& Heat Vent, Draft Curtain Interaction - Large Scale Experiments and Model Development, National Institute of Standards and Technology, Gaithersburg, MD., NISTIR 6196-1, September 1998.

3. McGrattan, Kevin B., Baum, Howard R., Rehm, Ronald G., Large Eddy Simulations of Smoke Movement, Fire Safety Journal, vol 30 (1998), p 161-178.

4. McGrattan, Kevin B., Forney, Glenn P., Fire Dynamics Simulator- User's Manual, National Institute of Standards and Technology, Gaithersburg, MD., NISTIR 6469, January 2000. 


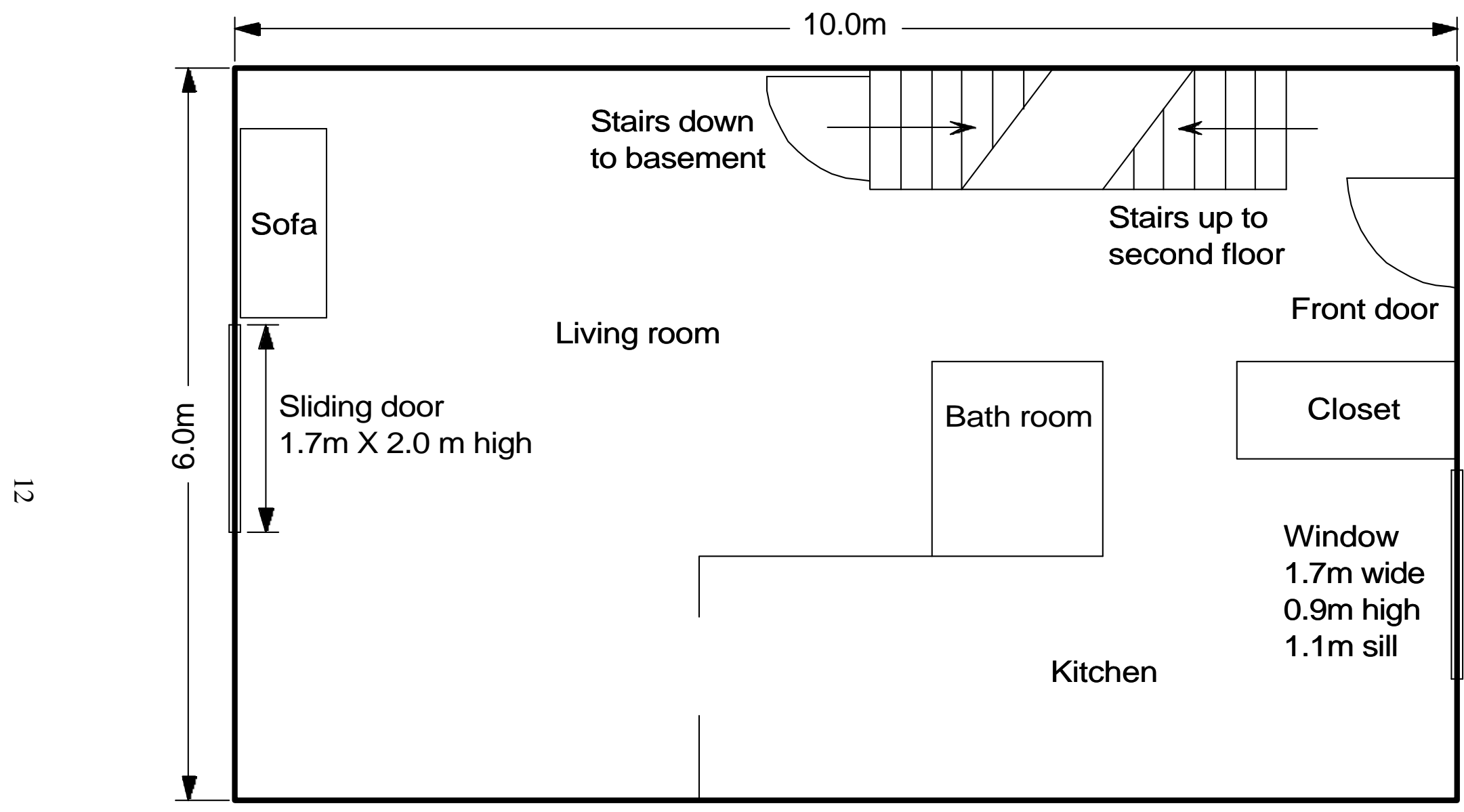

Figure 1. Plan view of first floor. 


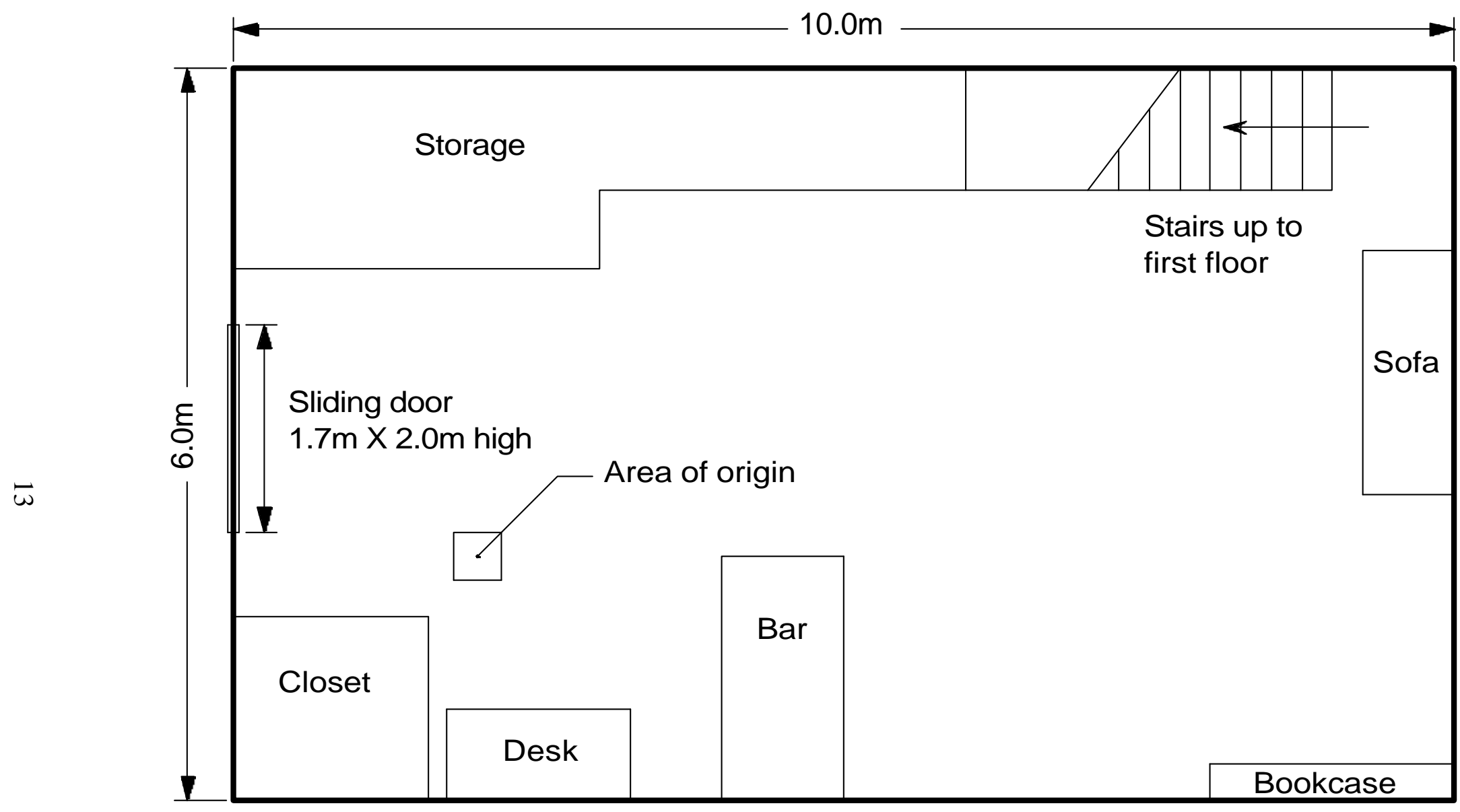

Figure 2. Plan view of basement. 


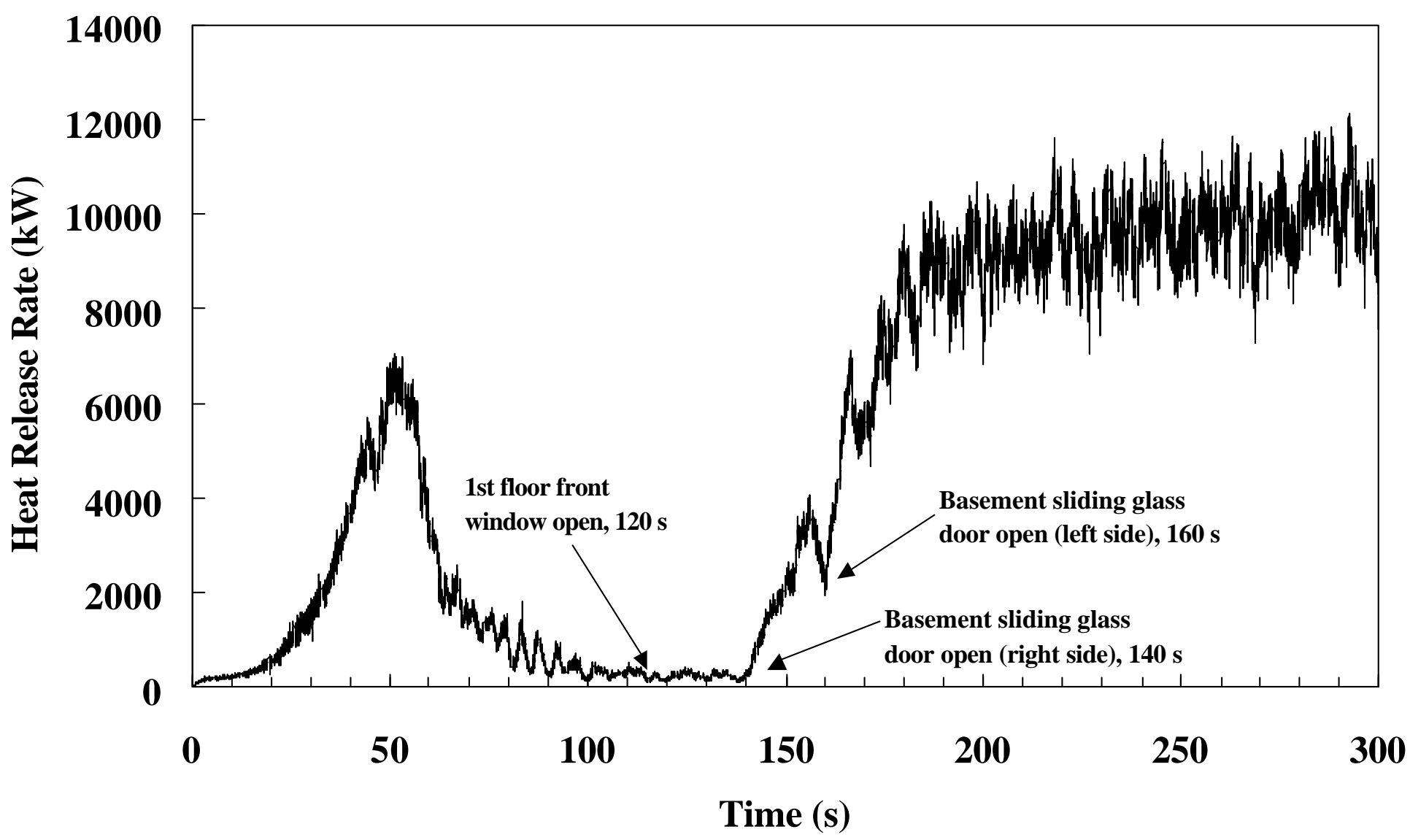

Figure 3. Heat release rate from FDS Simulation. 
NIST Smokeview 1.0.0

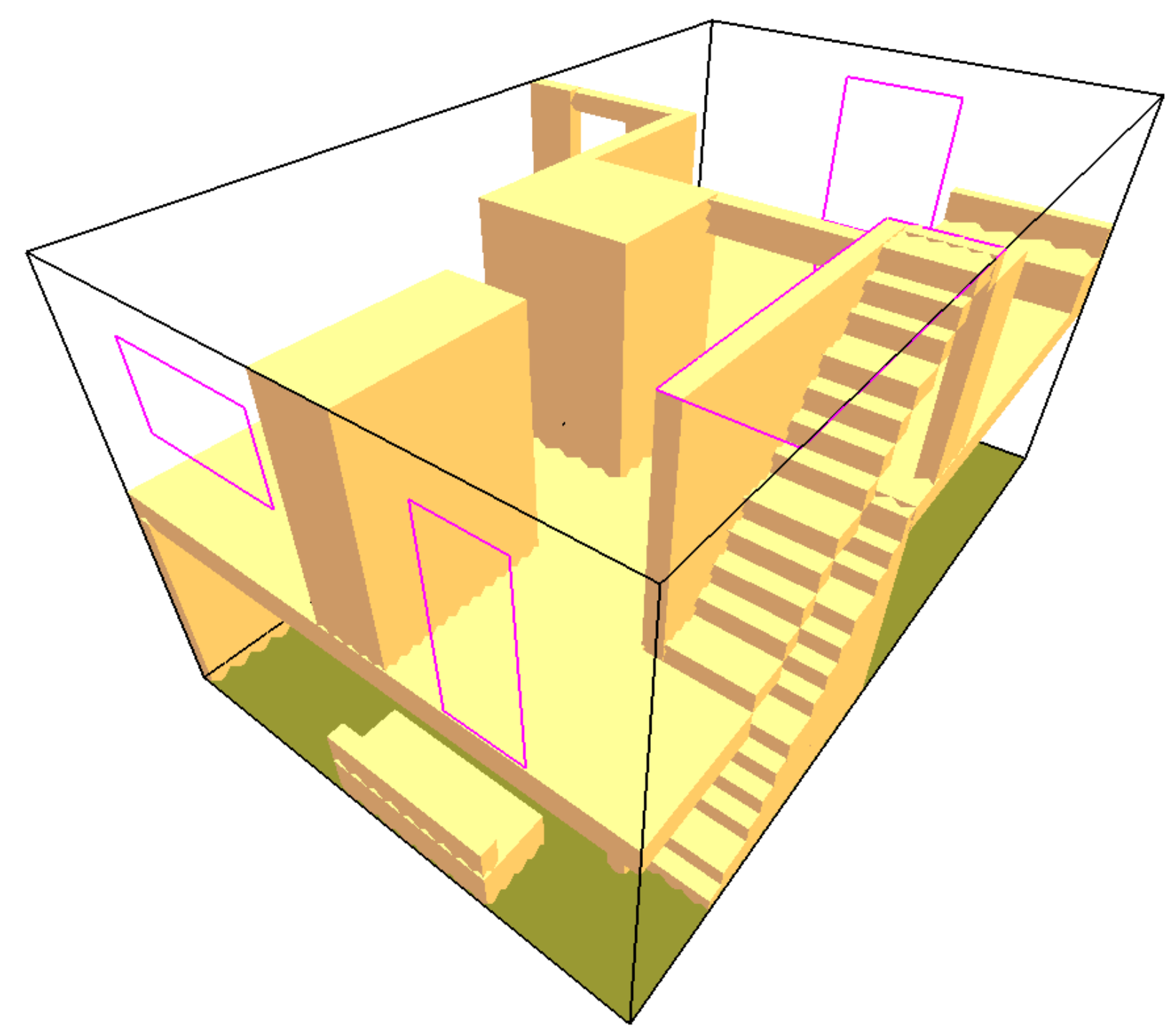

Figure 4. Perspective view of townhouse. 


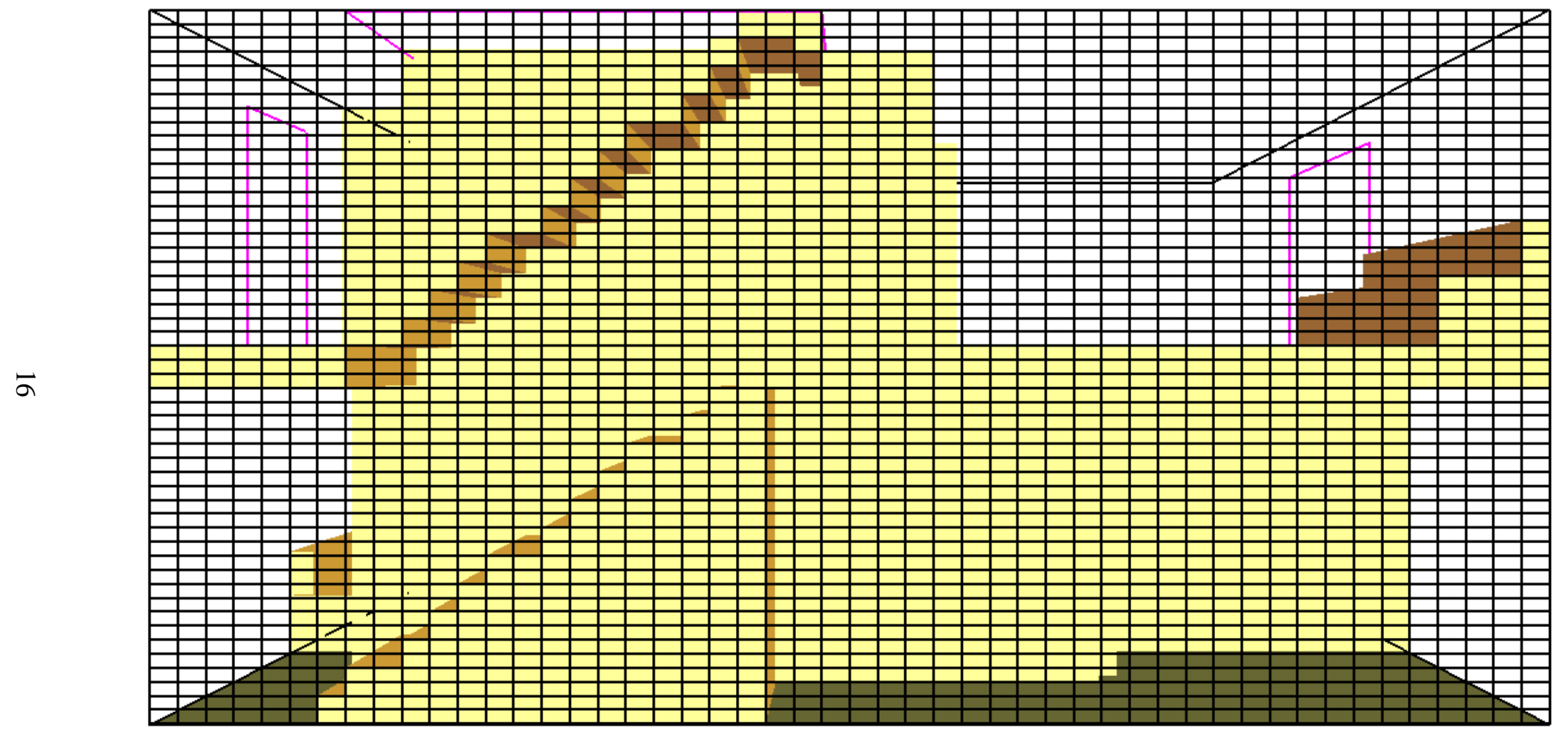




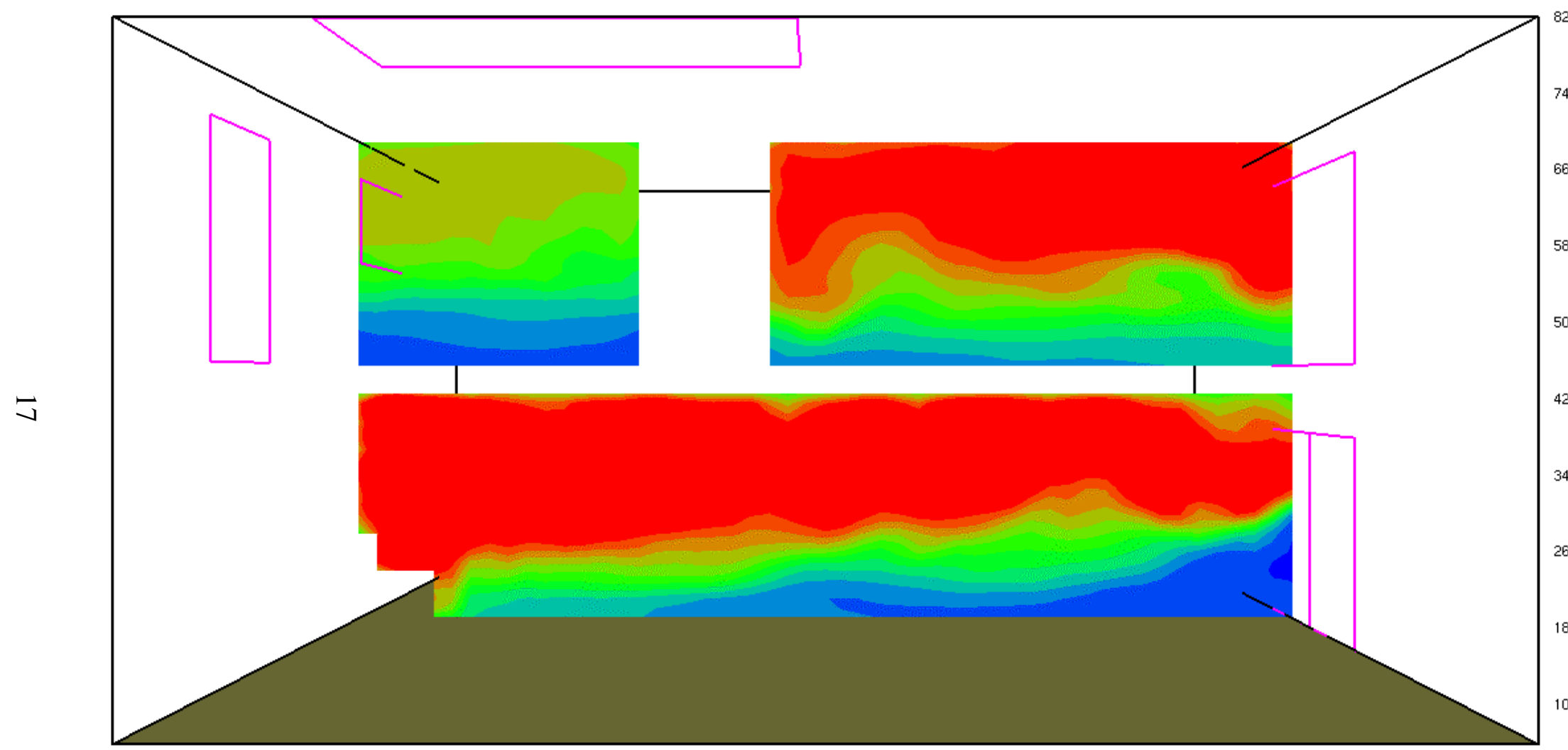

Figure 6. Temperature slice along basement sliding glass door, at 200 seconds of simulation. 


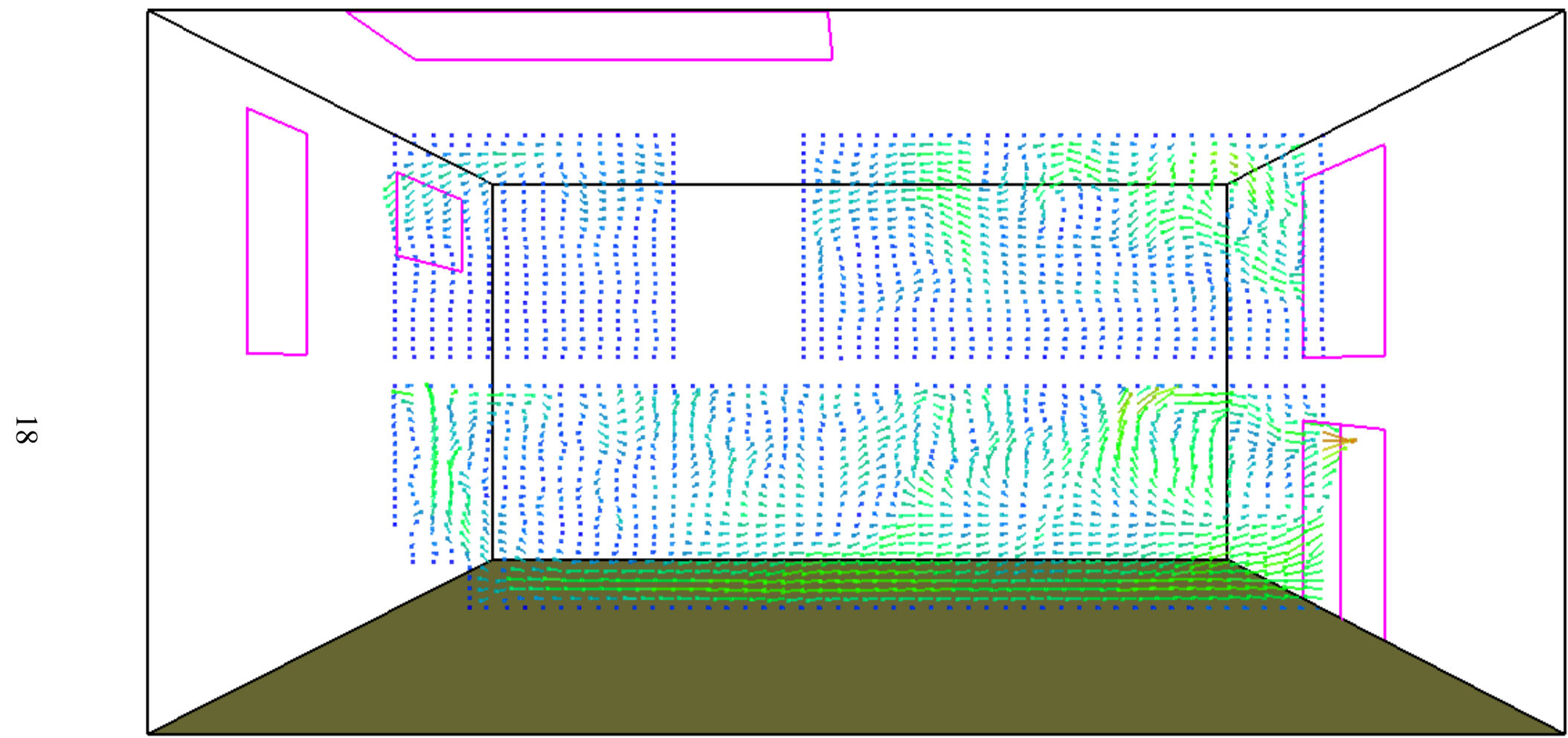

Figure 7. Vector representation of velocity slice along basement sliding glass door, at 200 seconds of simulation. 


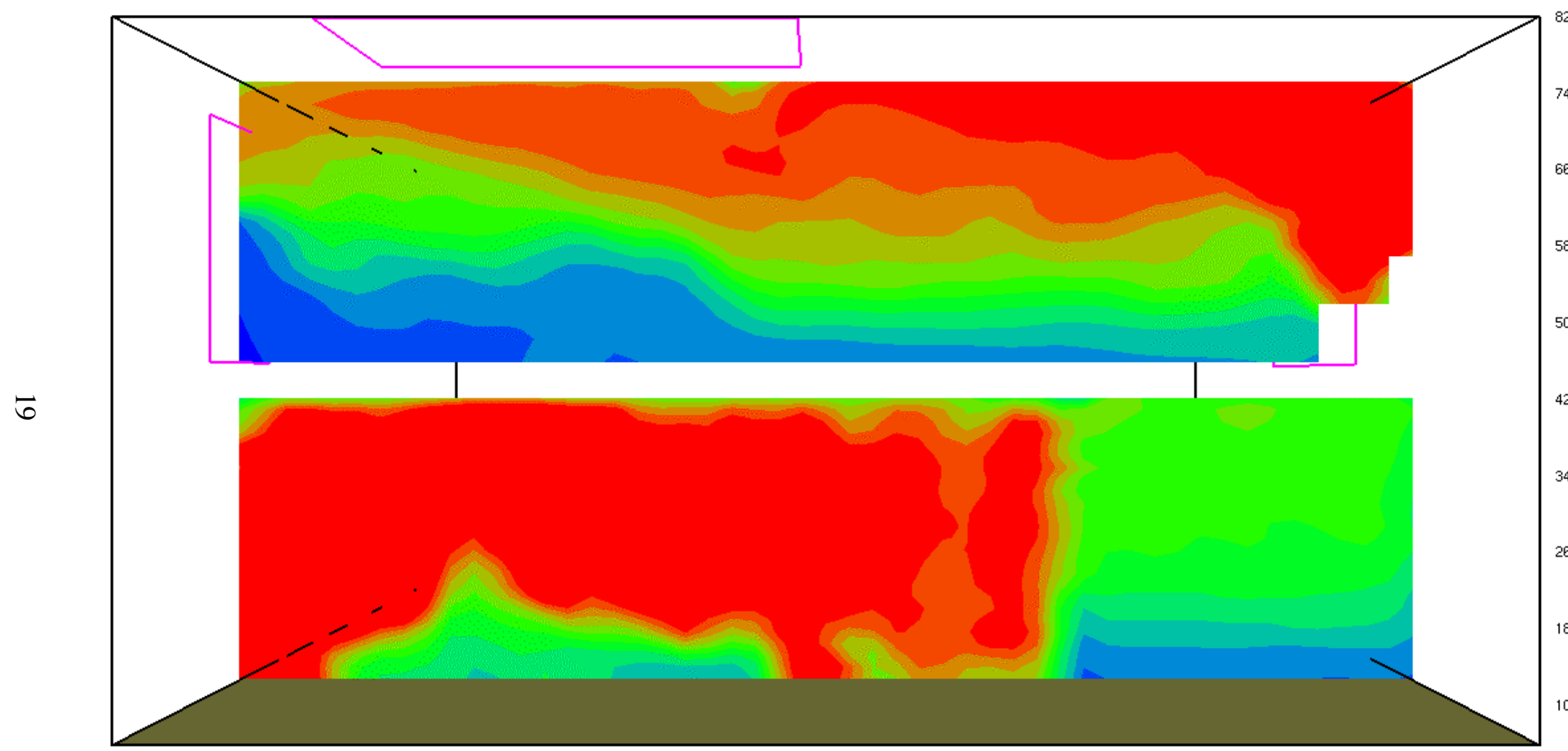

820

Figure 8. Temperature slice along front door, at 200 seconds of simulation. 


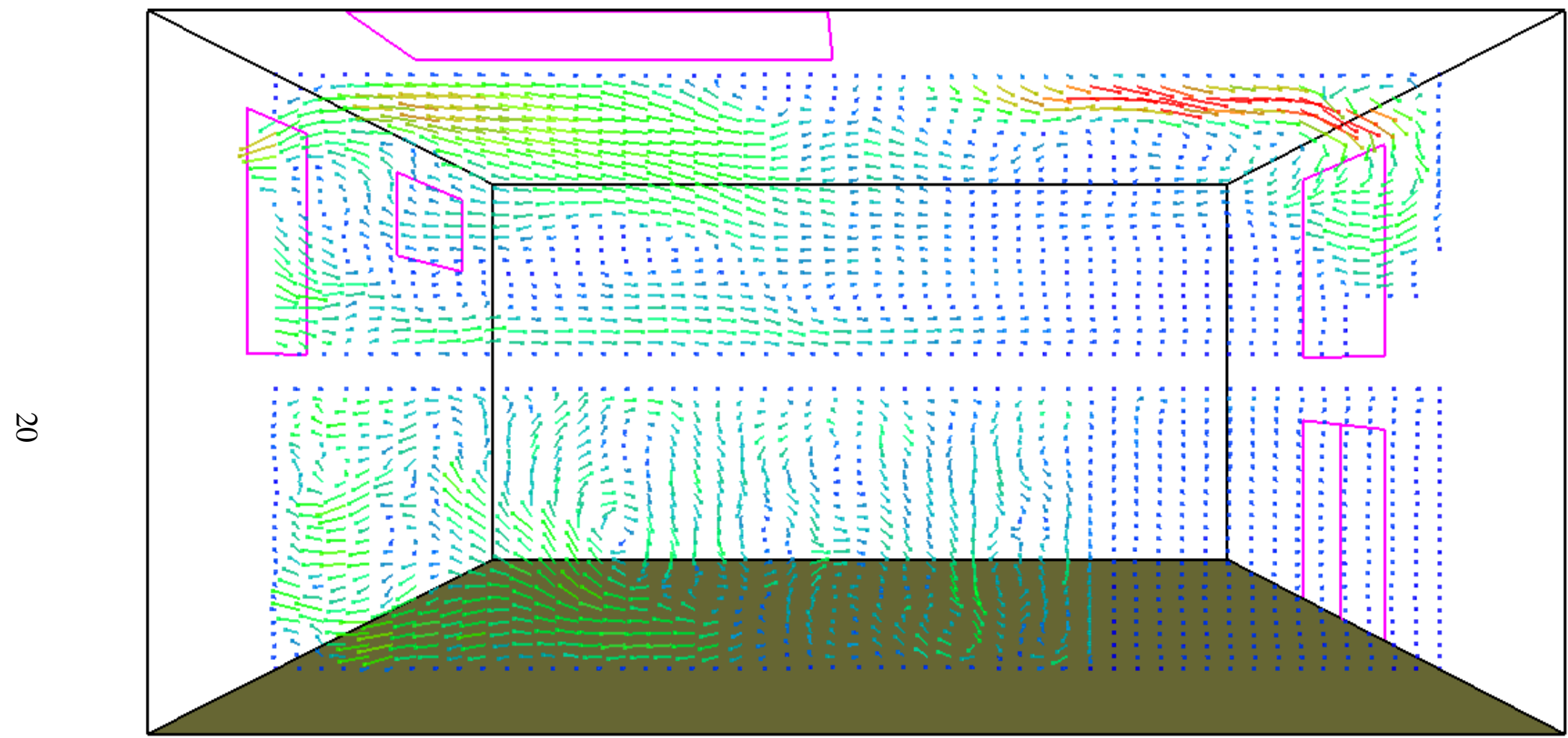

Figure 9. Vector representation of velocity slice along front door, at 200 seconds of simulation. 


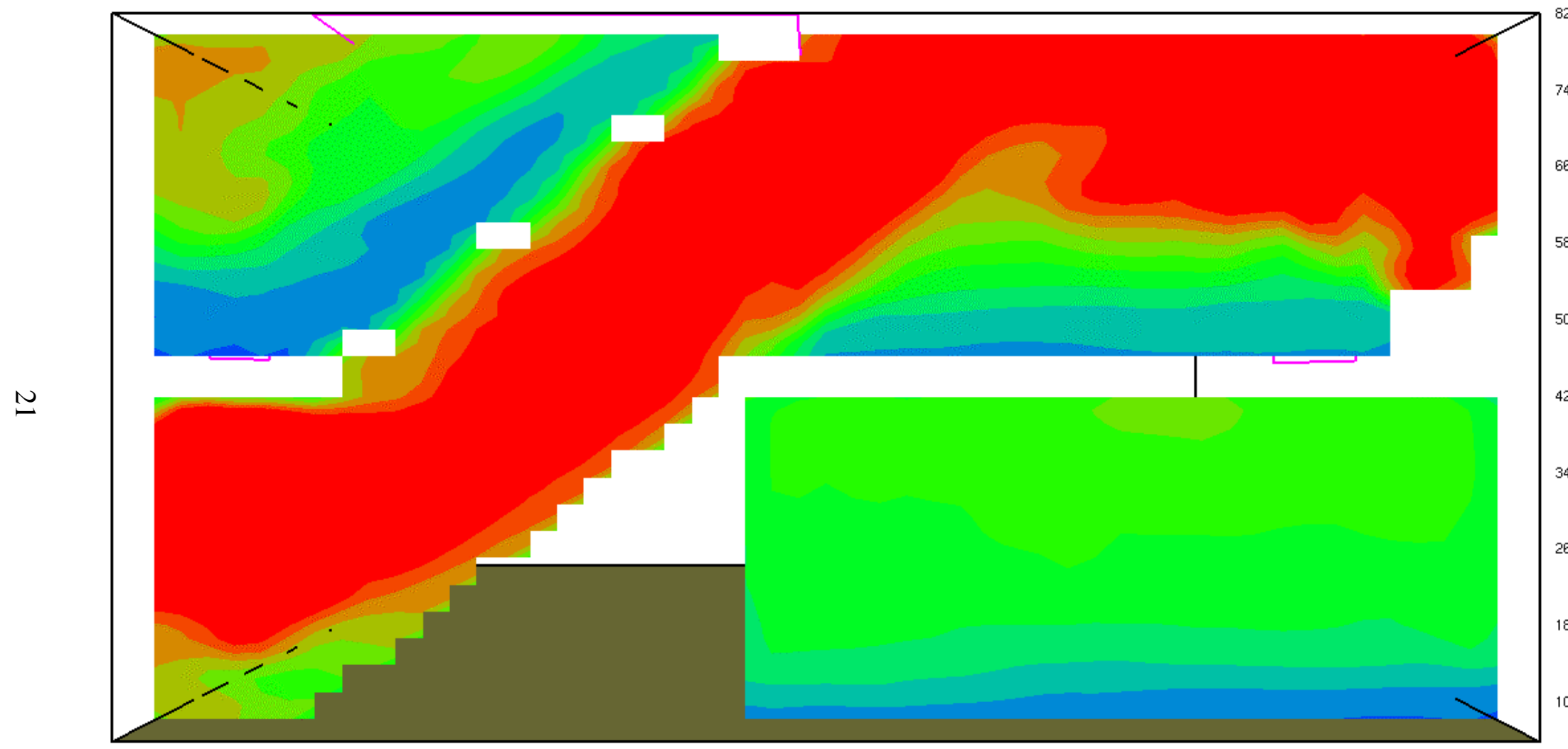

Figure 10. Temperature slice along centerline of stairway, at 200 seconds of simulation. 


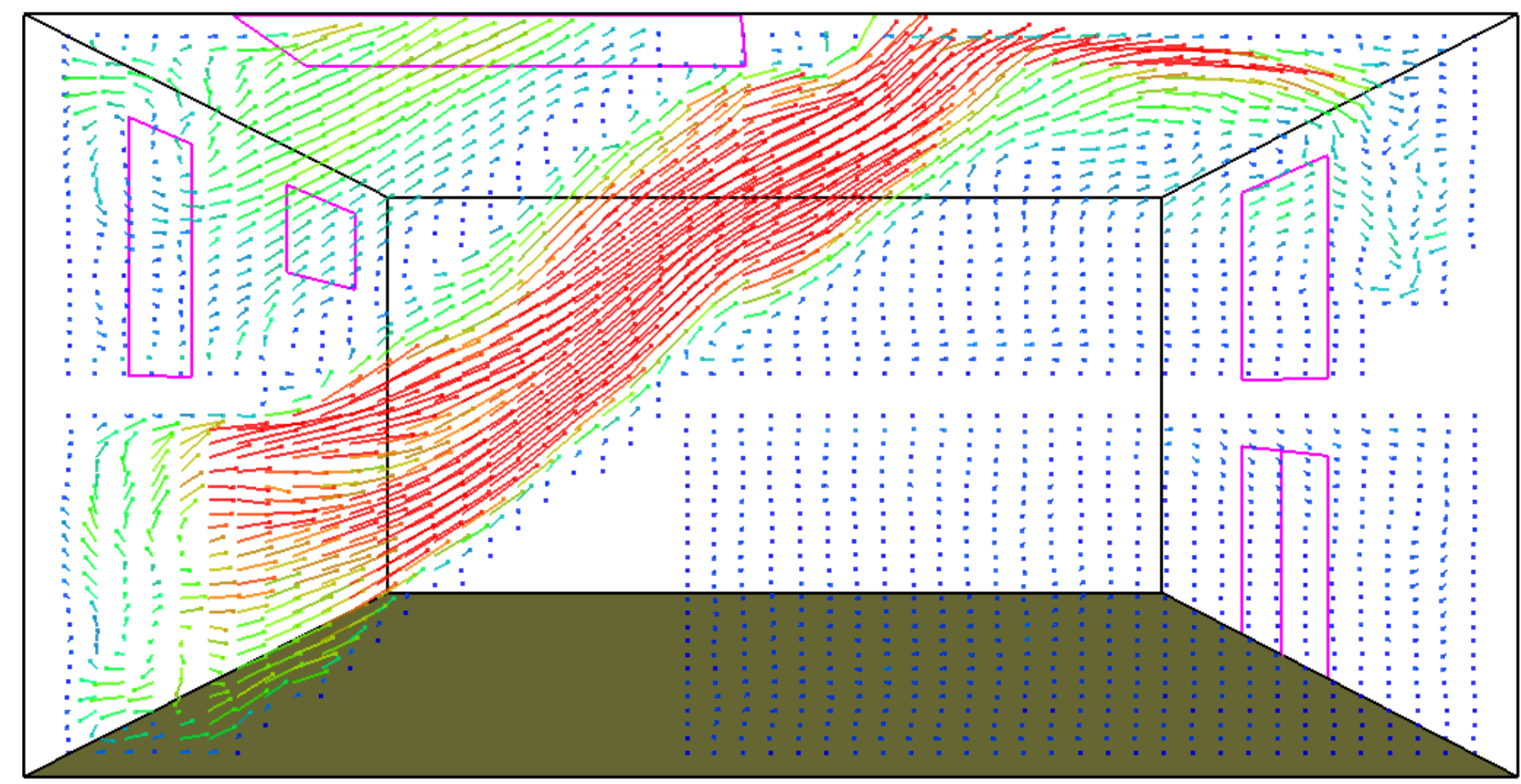

Figure 11. Vector representation of velocity along centerline of stairway, at 200 seconds of simulation. 
NIST Smokeview 1.0.1A

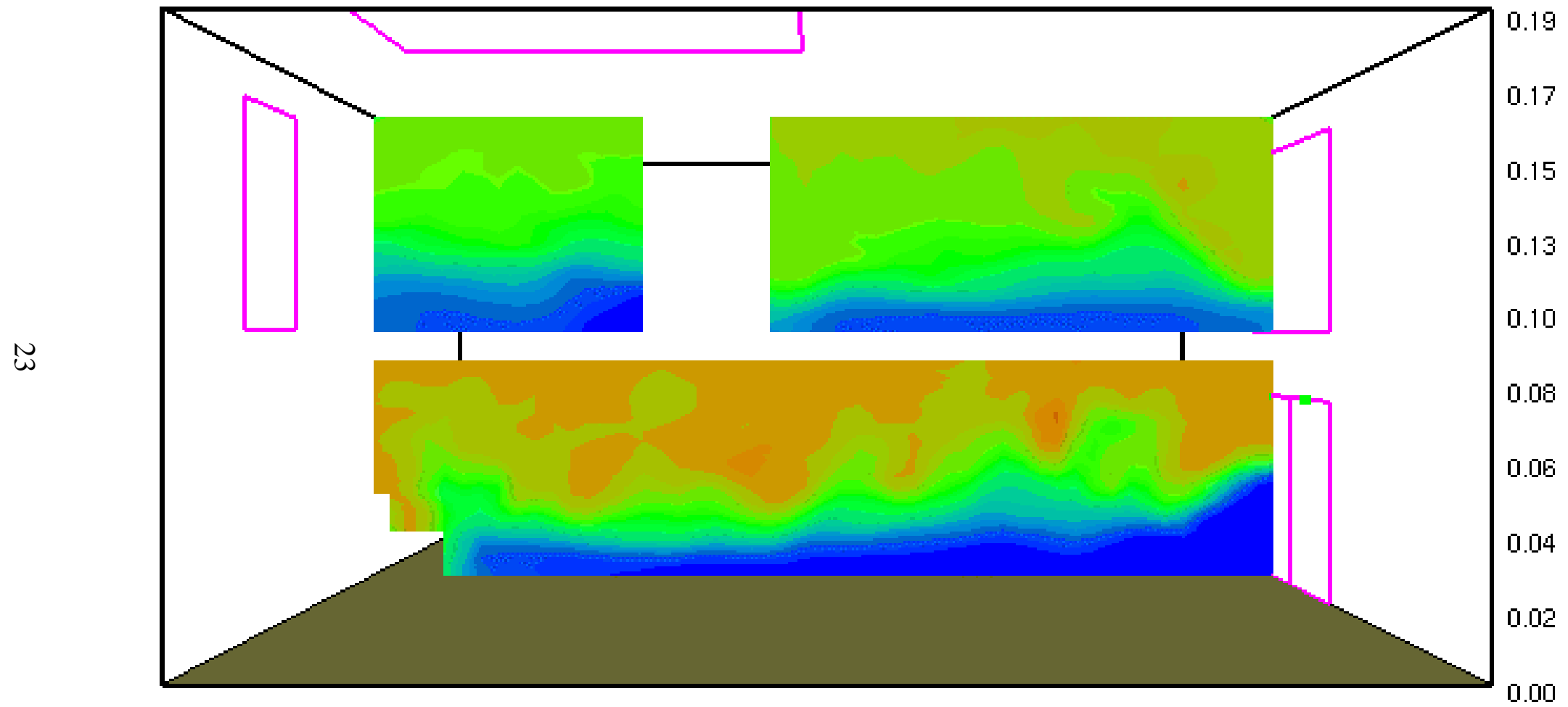

Figure 12. Percent oxygen along basement sliding glass door, at 200 seconds of simulation. 


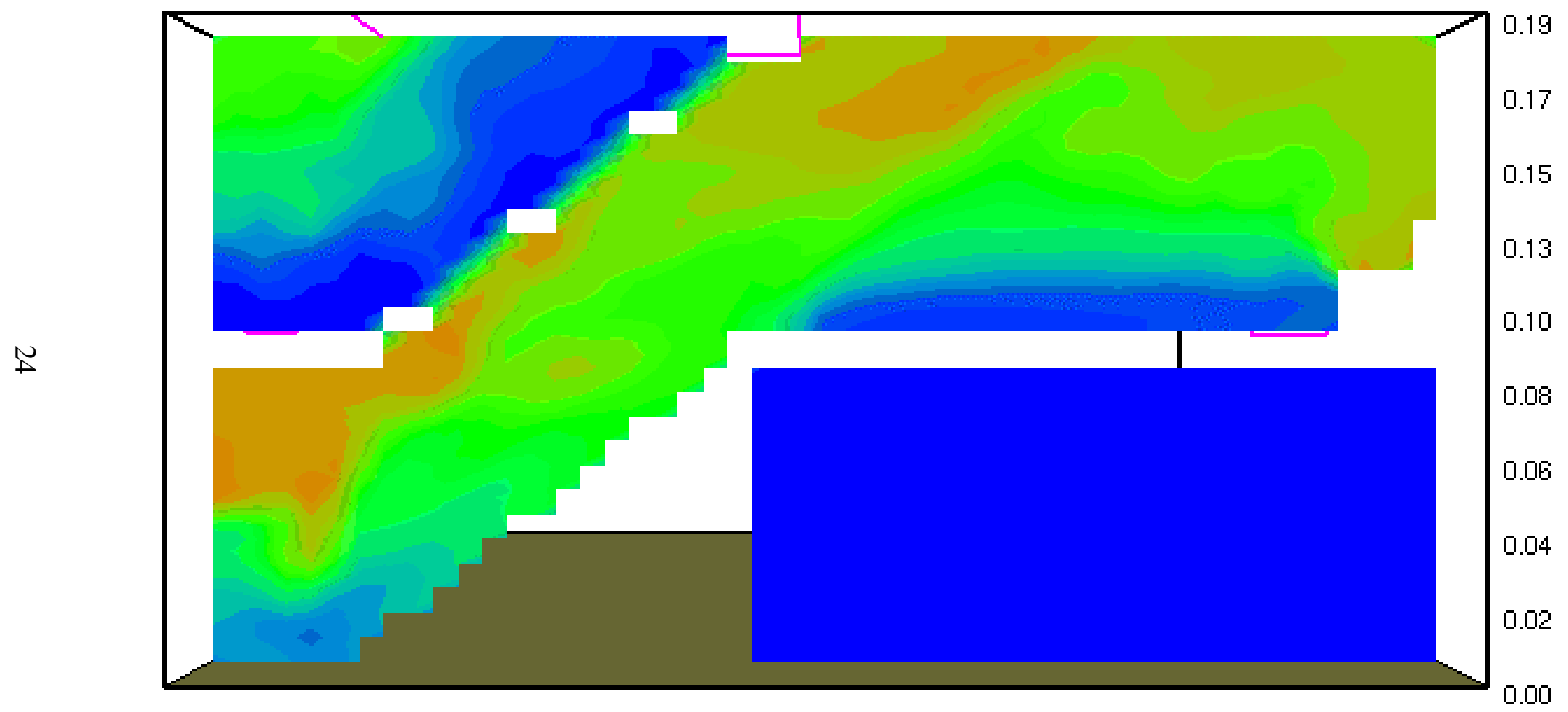

Figure 13. Percent oxygen along centerline of stairway, at 200 seconds of simulation. 


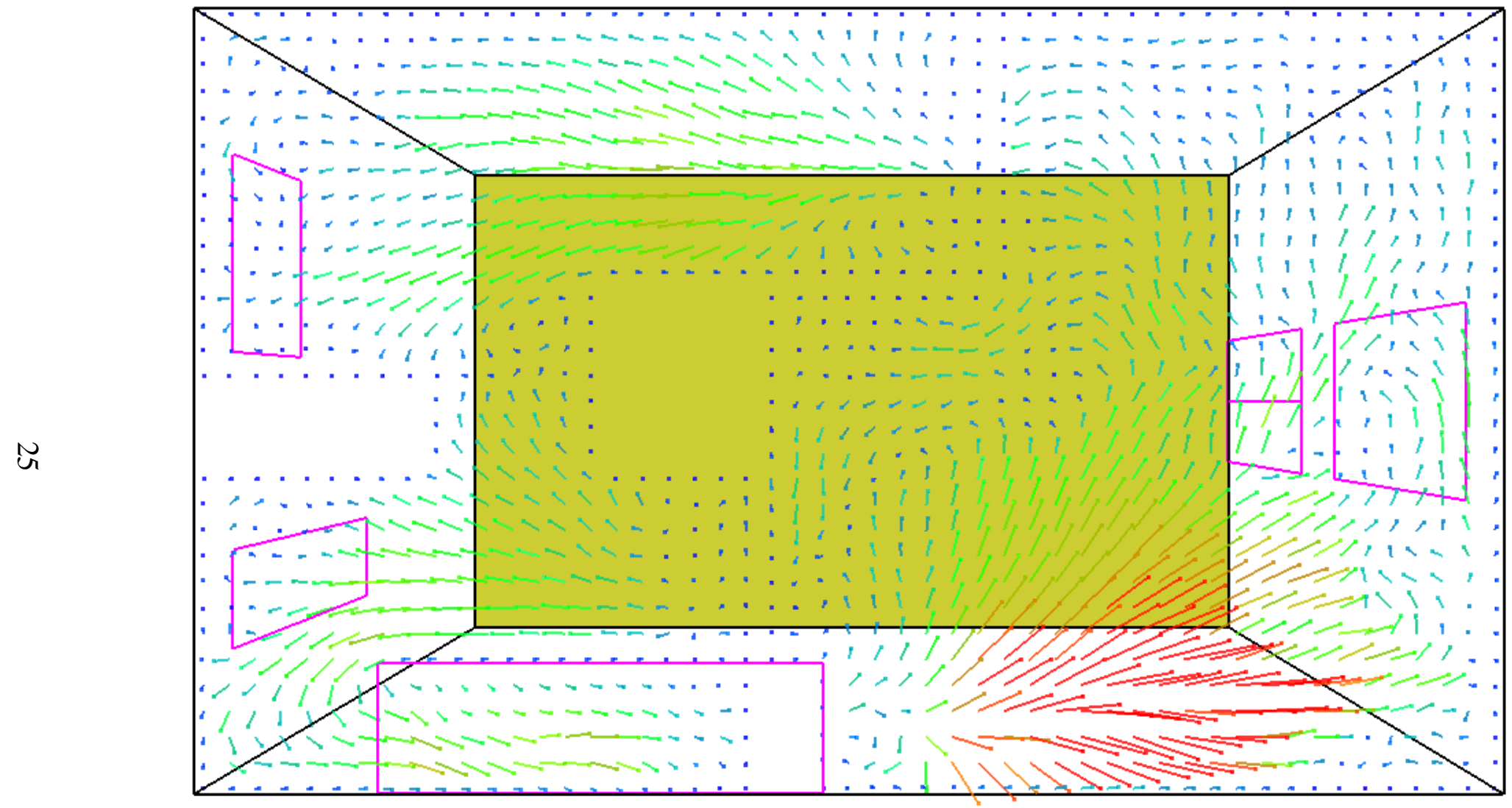

Figure 14. Vector representation of velocity at the ceiling, at 200 seconds of simulation. 


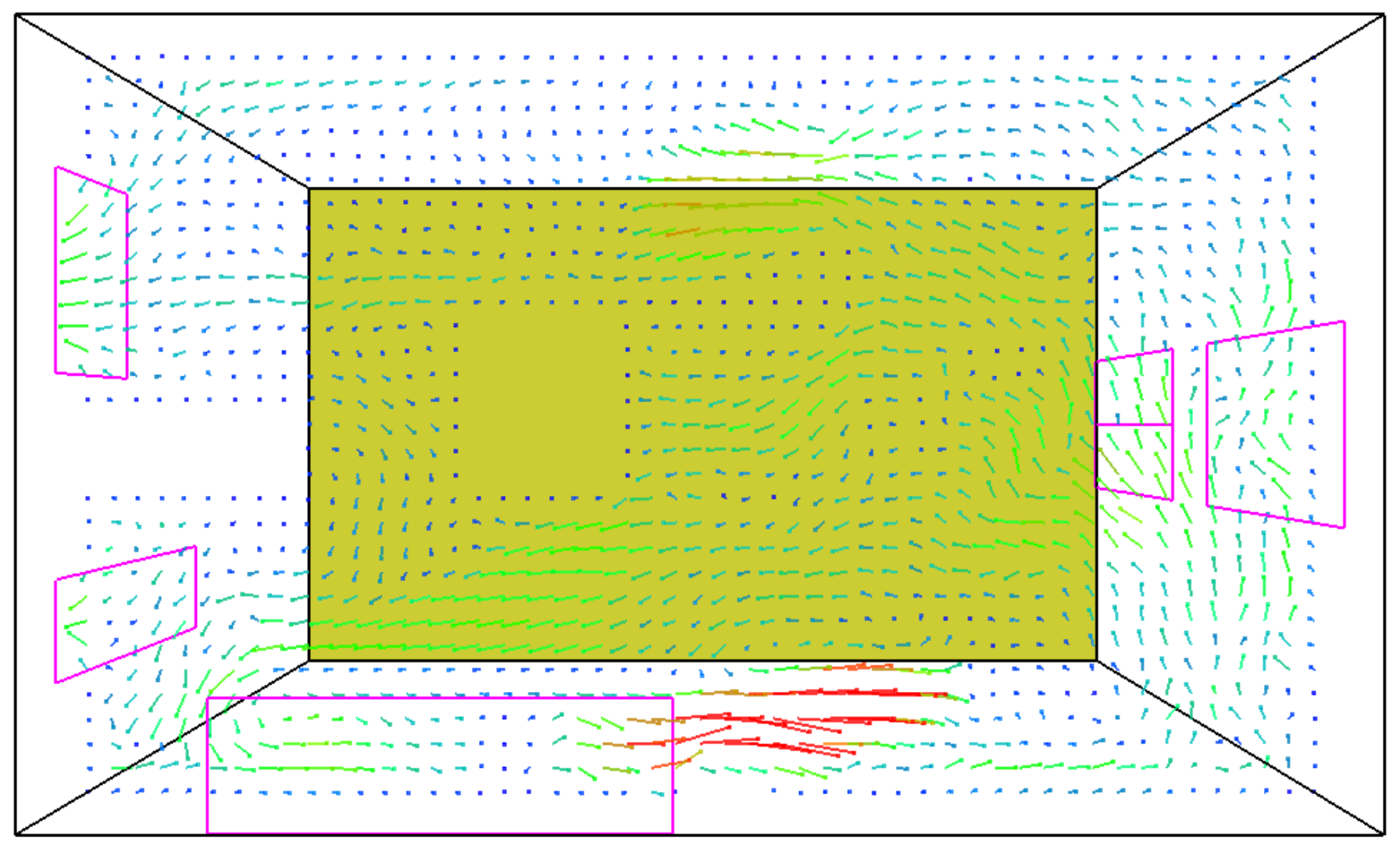

Figure 15. Vector representation of velocity at first floor window, $1.6 \mathrm{~m}$ off the floor, at 200 seconds of simulation. 


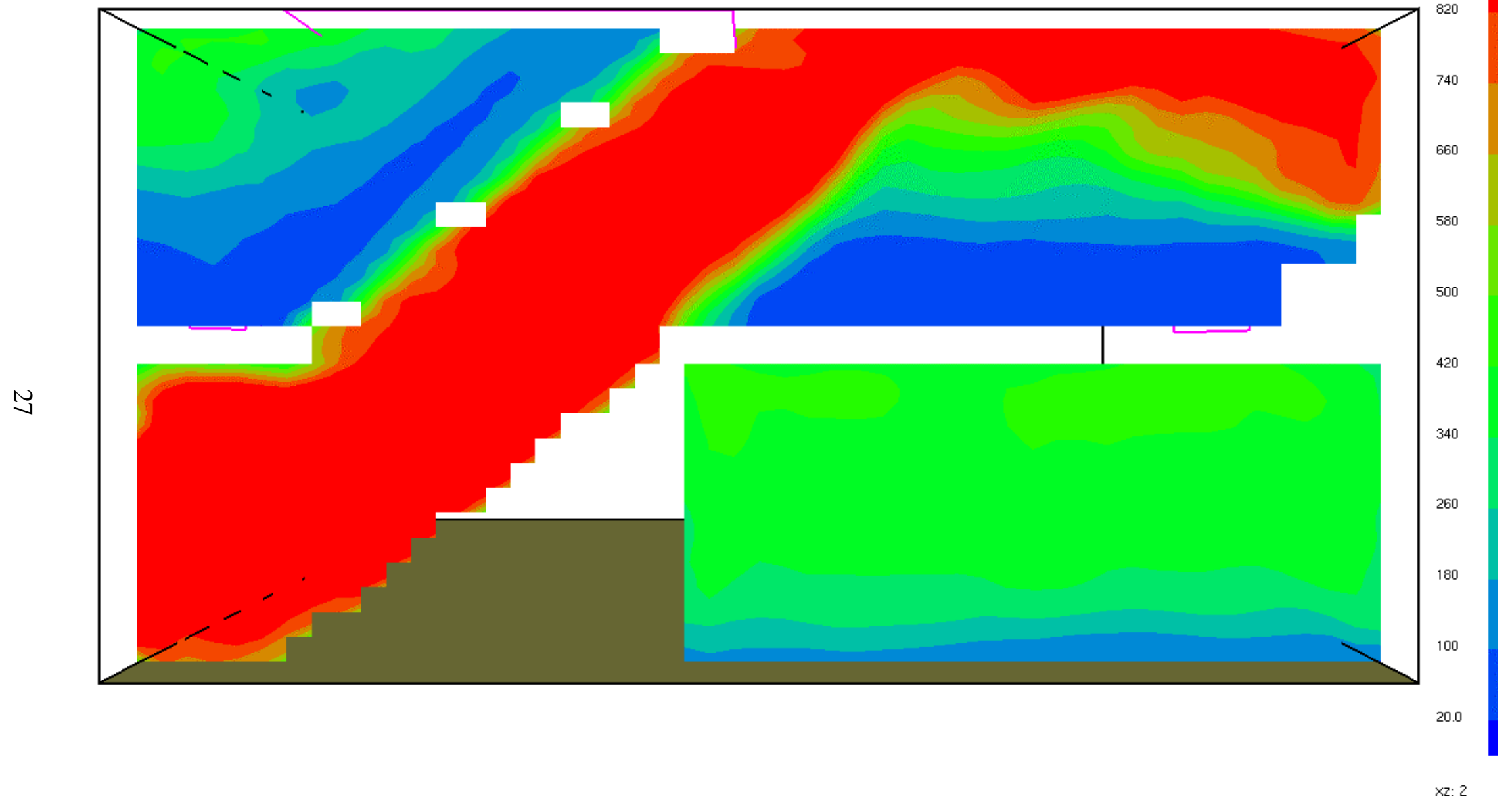

Figure 16. Temperature slice along center line of stairway with first floor sliding glass door vented, at 200 seconds of simulation. 


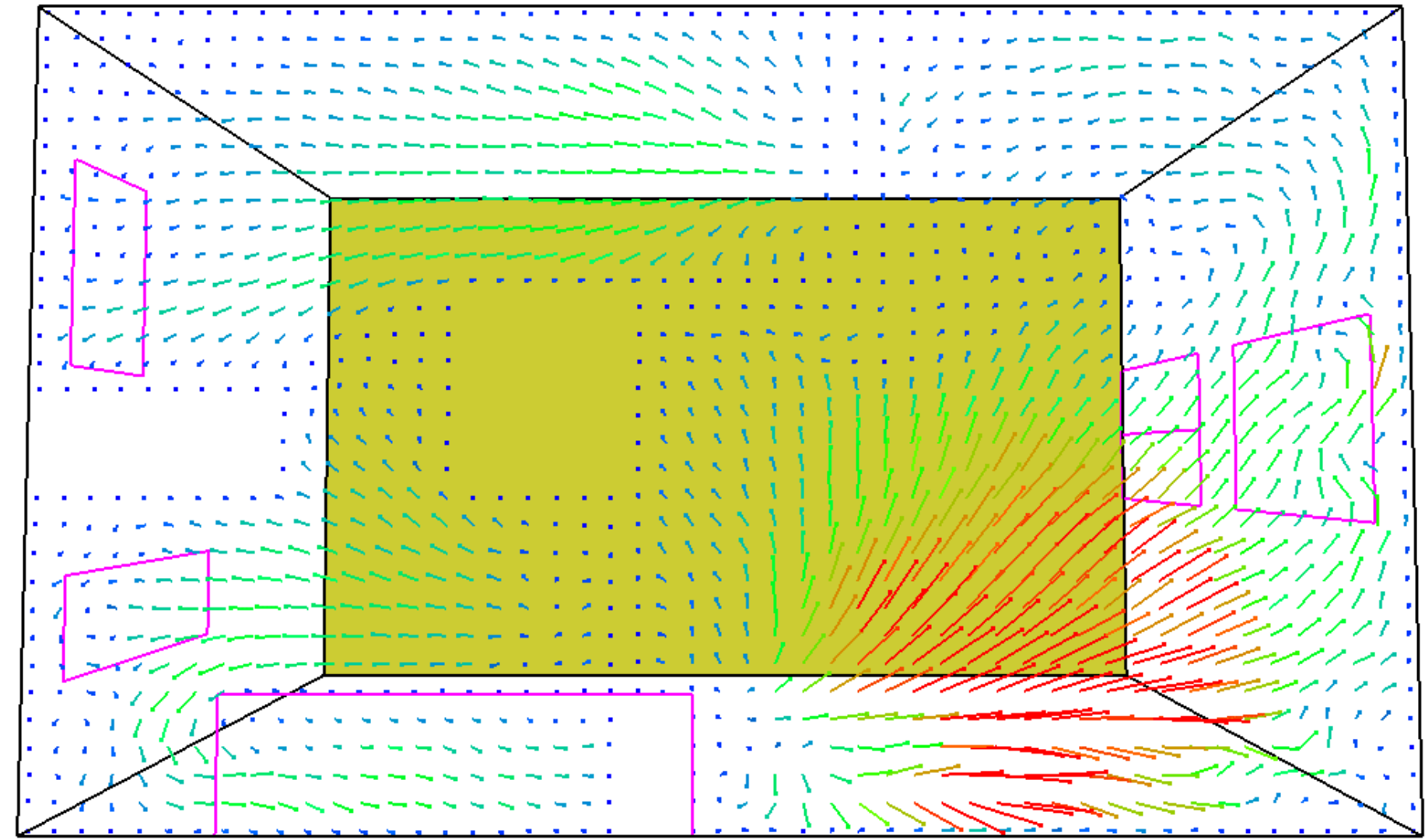

$8.5 \mathrm{~m} / \mathrm{s}$

Figure 17. Vector representation of velocity at the ceiling with first floor sliding glass door vented, at 200 seconds of simulation. 